\title{
Dietary L-arginine supplementation improves the intestinal development through increasing mucosal Akt and mammalian target of rapamycin signals in intra-uterine growth retarded piglets
}

\author{
Yuanxiao Wang, Lili Zhang, Genlai Zhou, Zhiyong Liao, Hussain Ahmad, Wenbin Liu and Tian Wang* \\ College of Animal Science and Technology, Nanjing Agricultural University, Nanjing, Jiangsu 210095, People's Republic \\ of China \\ (Submitted 3 May 2011 - Final revision received 9 November 2011 - Accepted 10 November 2011 - First published online 5 January 2012)
}

\section{Abstract}

Intra-uterine growth retardation (IUGR) impairs postnatal growth and development of the small intestine (SI) in neonatal pigs and infants. L-Arginine (Arg), a critical amino acid involved in promoting growth and metabolism in young mammals, is more deficient in IUGR fetuses. However, little is known whether dietary Arg supplementation would accelerate the impaired development of the SI induced by IUGR in piglets. In the present study, a total of six litters of newborn piglets were used. In each litter, one normal and two IUGR littermates were obtained. Piglets were fed milk-based diets supplemented with 0 (Normal), 0 (IUGR) and 0.60\% Arg (IUGR + Arg) from 7 to $14 \mathrm{~d}$ of age, respectively. Compared with Normal piglets at $14 \mathrm{~d}$ of age, IUGR decreased $(P<0.05)$ the growth performance, entire SI weight, and villus height in the jejunum and ileum. IUGR piglets had lower $(P<0.05)$ mucosal concentrations of Arg, insulin, insulin growth factor 1 , as well as phosphorylated Akt, mammalian target of rapamycin (mTOR) and p70 S6 kinase but higher $(P<0.05)$ enterocyte apoptosis index (AI). After Arg treatment in IUGR piglets, the growth performance, weight of entire SI and mucosa, and villus height in the jejunum and ileum were increased $(P<0 \cdot 05)$. Diet supplemented with Arg also increased $(P<0.05)$ the levels of Arg, insulin, phosphorylated Akt and mTOR in SI mucosa of IUGR piglets, and decreased $(P<0.05)$ the AI and caspase-3 activity. In conclusion, Arg has a beneficiary effect in improving the impaired SI development in IUGR piglets via regulating cell apoptosis and activating Akt and mTOR signals in SI mucosa.

\section{Key words: L-Arginine: Intra-uterine growth retardation: Small intestine: Piglets}

Mammalian intra-uterine growth retardation (IUGR) is characterised by impaired organ development and embryo/fetus growth during pregnancy ${ }^{(1,2)}$. It is mainly caused by uteroplacental insufficiency, intra-uterine infection, genetic defects, congenital malformations, environmental insults or severe malnutrition $^{(2,3)}$. In humans, IUGR affects $5-10 \%$ of all newborn infants ${ }^{(4)}$ and increases the risk of obesity, hypertension and type 2 diabetes mellitus in adulthood ${ }^{(5)}$. In livestock production such as the pig-rearing industry, $15-20 \%$ of all neonates suffer from this pregnancy condition ${ }^{(2)}$. Animals born with IUGR have increased neonatal morbidity and reduced metabolic efficiency, postnatal growth rate, meat quality and reproductive performance ${ }^{(2)}$. In neonatal piglets, IUGR also severely impairs the development and function of the gastrointestinal tract ${ }^{(6-8)}$, and this is the leading cause of malnutrition and delayed growth of IUGR piglets after birth ${ }^{(6)}$.

L-Arginine (Arg) is an essential amino acid for neonatal piglets, particularly under stressful conditions ${ }^{(9,10)}$. In sowreared piglets, only $<40 \%$ of Arg requirement can be met through breast-feeding ${ }^{(11,12)}$. It has been reported that dietary supplementation of Arg significantly promoted the growth of neonatal piglets ${ }^{(9,13)}$. In addition to postnatal growth, the embryonic development of animals is also affected by maternal Arg levels. Maternal Arg deficiency commonly leads to a higher incidence of preterm or IUGR in infants and newborn animals ${ }^{(10,14,15)}$. Supplementation of Arg during gestation increased the reproductive performance of gilts and the litter birth weight ${ }^{(16)}$. Thus, Arg has great potential in preventing and treating IUGR, as well as in promoting postnatal growth and health.

The small intestine (SI) is the site where the majority of food digestion and nutrient absorption occurs ${ }^{(17)}$. The development of the SI appears to be faster than many other organs in piglets within the first four postnatal weeks ${ }^{(18)}$. Previous studies have demonstrated that the ratio between the number of apoptotic and proliferating enterocytes can be used as the marker for intestinal mucosal maturation ${ }^{(18)}$. However, it is unclear whether the impaired SI development in IUGR neonates is due to increased apoptosis or decreased cell proliferation. Akt, a protein kinase also referred to as protein kinase $\mathrm{B}$,

Abbreviations: AI, apoptosis index; Arg, L-arginine; BW, body weight; Cit, citrulline; IGF-1, insulin growth factor 1; IUGR, intra-uterine growth retardation; mTOR, mammalian target of rapamycin; Orn, ornithine; PI, proliferation index; Pro, proline; S6K1, p70 S6 kinase; SI, small intestine.

*Corresponding author: T. Wang, fax +86 25 84395156, email tianwang@njau.edu.cn 
plays a critical role in promoting cell survival by inhibiting apoptosis ${ }^{(19,20)}$. The activation of Akt by insulin and many other growth factors ${ }^{(19)}$ can directly phosphorylate mammalian target of rapamycin $(\mathrm{mTOR})^{(21)}$. The phosphorylated mTOR activates its effectors, p70 S6 kinase (S6K1) and eukaryotic translation initiation factor 4E-binding protein 1, to initiate translation and stimulate protein synthesis and cell growth $^{(22,23)}$. It has been reported that Arg supplementation in the diet of neonatal piglets enhanced mTOR signalling in skeletal muscle ${ }^{(13)}$. Similarly, in vitro studies have shown that Arg stimulates protein synthesis in intestinal epithelial cells by enhancing mTOR/S6K1 signalling ${ }^{(24-26)}$. In addition, dietary Arg supplementation enhanced intestinal growth and development in 21-d-old normal piglets ${ }^{(27)}$. However, it is still unknown whether Arg supplementation would have beneficial effects on the development of the SI in IUGR neonatal piglets. Therefore, we hypothesised that oral Arg supplementation would regulate SI growth and development in the neonatal IUGR piglets through enhancing the activation of Akt and mTOR and reducing the ratio between apoptosis and proliferation in the SI mucosa. Since the pig is also an ideal animal model for studying human nutritional and digestive disorders ${ }^{(17)}$, results from the present study will also have direct relevance to the understanding of human nutrition.

\section{Materials and methods \\ Milk replacer diets}

Experimental diets used for the present study were prepared by supplementing with either $0.60 \%(\mathrm{w} / \mathrm{w})$ Arg (Arg diet) or $1 \cdot 23 \%(\mathrm{w} / \mathrm{w}) \mathrm{L}$-alanine (Control diet) in the basic milk replacer powder to be isoenergetic and isonitrogenous (Table 1). Basic milk replacer powder was formulated according to previous studies ${ }^{(13)}$. The ingredients of the formulation were purchased from Tianke and Hejia Company; and Arg and L-alanine were provided by Ajinomoto (China) Company Limited. The dosage of supplemental Arg (0.60\%) was chosen according to previous studies in 7 -d-old piglets ${ }^{(9,13)}$. The level of Arg in the control milk replacer diet was $0.59 \%(\mathrm{w} / \mathrm{w})$, as analysed according to the methods of the Association of Official Analytical Chemists ${ }^{(28)}$. The diets were prepared by mixing $1 \mathrm{~kg}$ of milk replacer powder (DM 87.5\%) with $4000 \mathrm{ml}$ of water to a final $5030 \mathrm{ml}$ of milk solution and were given to piglets by bottle feeding six times per $24 \mathrm{~h}^{(13,29)}$.

\section{Animals and treatment}

All the procedures were approved by the Institutional Animal Care and Use Committee of Nanjing Agricultural University. A gestating diet formulated to meet National Research Council $^{(30)}$ nutrient requirements was fed ad libitum to the pregnant sows with a similar birth order (3rd or 4th) during the entire period of pregnancy, as was drinking water. At the time of parturition (day 114 (SD 1) of gestation), newborn piglets (Duroc $\times($ Landrace $\times$ Yorkshire) $)$ from six sows with the same litter size (ten piglets/litter) were selected
Table 1. Composition and nutrient content of diets ( $87.5 \% \mathrm{DM}$ basis)

\begin{tabular}{|c|c|c|}
\hline Items & Control & $\operatorname{Arg}^{\star}$ \\
\hline \multicolumn{3}{|l|}{ Ingredients (\%) } \\
\hline Whey protein concentrate $(34 \% \mathrm{CP})$ & $60 \cdot 00$ & $60 \cdot 00$ \\
\hline Milk fat powder (11\% CP) & $26 \cdot 00$ & $26 \cdot 00$ \\
\hline$\alpha$-Casein & $6 \cdot 20$ & $6 \cdot 20$ \\
\hline Lactose & 3.60 & $3 \cdot 60$ \\
\hline Glucose & 0.42 & 1.05 \\
\hline Calcium lactate $(13 \% \mathrm{Ca})$ & $1 \cdot 00$ & 1.00 \\
\hline $\mathrm{CaH}_{2} \mathrm{PO}_{4}(22 \% \mathrm{P})$ & $1 \cdot 00$ & $1 \cdot 00$ \\
\hline Vitamin mixture $†$ & 0.10 & $0 \cdot 10$ \\
\hline Mineral mixture $\ddagger$ & 0.20 & $0 \cdot 20$ \\
\hline L-Ala & $1 \cdot 23$ & 0.00 \\
\hline L-Arg & 0.00 & 0.60 \\
\hline L-Met & 0.10 & $0 \cdot 10$ \\
\hline L-Lys-HCl & 0.10 & 0.10 \\
\hline Terramycin- $\mathrm{HCl}$ & 0.05 & 0.05 \\
\hline Total & $100 \cdot 00$ & $100 \cdot 00$ \\
\hline \multicolumn{3}{|l|}{ Nutrient content§ } \\
\hline CP (\%) & $25 \cdot 94$ & 25.92 \\
\hline Gross energy (MJ/kg) & $17 \cdot 77$ & $17 \cdot 78$ \\
\hline Digestible energy (MJ/kg) & $14 \cdot 38$ & $14 \cdot 38$ \\
\hline $\mathrm{Ca}(\%)$ & 0.90 & 0.91 \\
\hline Total P (\%) & 0.68 & 0.69 \\
\hline Available P (\%) & 0.42 & 0.43 \\
\hline Lys (\%) & 1.59 & 1.58 \\
\hline Met $(\%)$ & 0.53 & 0.54 \\
\hline L-Arg (\%) & 0.59 & $1 \cdot 12$ \\
\hline
\end{tabular}

Arg, L-arginine; CP, crude protein.

* In the Arg diets, $1.23 \%$ L-alanine was replaced by $0.60 \%$ Arg (expressed on the basis of milk replacer powder). The two diets were isonitrogenous and isoenergetic.

† Vitamin mixture provided per $\mathrm{mg} / \mathrm{kg}$ powder diet: retinyl acetate, 0.76 ; cholecalciterol, 0.055; all-rac- $\alpha$-tocopheryl acetate, 16; menadione sodium bisulphate, 0.50 ; cyanocobalamin, 0.02 ; riboflavin, 4.0; niacin, 20; pantothenic acid, 12; choline chloride, 600; colic acid, 0.30; thiamine, 1.5; pyridoxine, 2.0; biotin, 0.08.

† Mineral mixture provided per mg/kg powder diet: $\mathrm{Zn}$ (as $\left[\mathrm{C}_{5} \mathrm{H}_{11} \mathrm{NO}_{2} \mathrm{~S}\right]_{2} \mathrm{Zn}$ ), 100; $\mathrm{Mn}$ (as $\left[\mathrm{C}_{2} \mathrm{H}_{4} \mathrm{~N}_{2} \mathrm{O}_{2}\right]_{2} \mathrm{Mn}$ ), 5.0; $\mathrm{Fe}$ (as $\left[\mathrm{C}_{5} \mathrm{H}_{4} \mathrm{O}_{2} \mathrm{~N}\right]_{2} \mathrm{Fe}$ ), 100; $\mathrm{Cu}$ (as $\left[\mathrm{C}_{2} \mathrm{H}_{5} \mathrm{NO}_{2}\right]_{2} \mathrm{Cn}$ ), 10; I (as KI), 0.2; $\mathrm{Se}$ (as $\left.\mathrm{Na}_{2} \mathrm{SeO}_{3}\right), 0.3$.

$\S$ All nutrient contents, except digestible energy, were analysed values.

for this study. In each litter, one normal piglet with body weight (BW) of 1.57 (SD 0.13) kg and two IUGR littermates with BW of $0.90(\mathrm{SD} 0 \cdot 12) \mathrm{kg}$ were chosen according to previous studies ${ }^{(5,6,31)}$. All piglets were weaned at $7 \mathrm{~d}$ of age and were fed with liquid diets at $75 \mathrm{ml} / \mathrm{kg} \mathrm{BW}$ per meal every $4 \mathrm{~h}$ by bottle feeding between 7 and $14 \mathrm{~d}$ of age ${ }^{(29)}$. In each litter, one of the IUGR piglets (IUGR control, $n$ 6) and normal littermate (Normal control, $n$ 6) received the control diet, and the other IUGR littermate received the Arg diet (IUGR + Arg, $n$ 6). The Arg intake by Normal and IUGR piglets fed the control diet was $0 \cdot 418 \mathrm{~g} / \mathrm{kg}$ BW per $\mathrm{d}$, which was similar to the piglets fed by sows. All piglets were housed individually in plastic floored pens $(1.5 \mathrm{~m} \times 0.5 \mathrm{~m})$ at an ambient temperature of $33^{\circ} \mathrm{C}$ in an environmentally controlled room and had free access to water.

\section{Tissue sampling}

From each group, four piglets with nearly equal BW, at $14 \mathrm{~d}$ of age, were selected for tissue collection. The piglets were killed by intramuscular injection of sodium pentobarbital $(50 \mathrm{mg} / \mathrm{kg}$ $\mathrm{BW})$ at $2 \mathrm{~h}$ after the last meal. The entire SI starting from the pyloric sphincter to the ileocecal valve was removed from the abdominal cavity and divided into four segments, 
including the duodenum, proximal and distal jejunum, and ileum ${ }^{(32)}$. Each intestinal segment was immediately flushed with ice-cold physiological saline to remove luminal contents, and weighed after careful removal of the mesenteric attachments. The length of the entire SI was measured by a metric ruler. Sections of approximately $1 \mathrm{~cm}$ in length were carefully collected from the mid of each segment, and fixed in $4 \%$ $(\mathrm{w} / \mathrm{v})$ paraformaldehyde in $100 \mathrm{~mm}-\mathrm{PBS}, \mathrm{pH} 7.4$ for $24 \mathrm{~h}$ for histological and immunohistochemical analyses. Jejunal mucosa was scraped from the rest of the tissue using a glass microscope slide ${ }^{(6,31)}$, and was immediately frozen in liquid $\mathrm{N}_{2}$ for protein and hormone analyses.

\section{Measurement of growth factors in small intestine mucosa}

The insulin and insulin growth factor 1 (IGF-1) levels in the jejunal mucosa were determined using commercial ELISA kits (USCN Life Science Corporation) following the manufacturer's protocols. The supernatant of the mucosal homogenate was prepared according to a previous study in our laboratory ${ }^{(31)}$. The concentration of protein was measured using Lowry's method ${ }^{(33)}$. Values of insulin and IGF-1 were expressed as per $\mathrm{g}$ wet tissue and per mg protein basis.

\section{Analysis of amino acids in small intestine mucosa}

Norleucine was added to $100 \mathrm{mg}$ of jejunal mucosa, and homogenised in a mixture of $10 \mathrm{ml}$ trifluoroacetic acid and $100 \mathrm{ml}$ methanol, followed by centrifugation at $3500 \mathrm{~g}$ for $5 \mathrm{~min}$ at $4^{\circ} \mathrm{C}^{(34)}$. The concentrations of amino acids were analysed by reverse-phase HPLC (HP1100; Agilent) following a method described previously ${ }^{(35)}$.

\section{Morphological analysis}

SI sections $(5 \mu \mathrm{m})$ were prepared from paraffin-embedded samples and stained with haematoxylin and eosin. Villus height, villus width and crypt depth of twenty well-oriented villi per section were measured using a Nikon ECLIPSE 80i light microscope with a computer-assisted morphometric system (Nikon Corporation).

\section{Apoptosis and proliferation}

To evaluate cell proliferation in the intestinal crypt, Ki67, a marker for proliferative activity was determined using the streptavidin-perosidase method ${ }^{(36)}$. Briefly, SI sections (distal jejunum segment, $5 \mu \mathrm{m}$ thick) were deparaffinised in xylene, dehydrated with alcohol and rehydrated in PBS. Endogenous peroxidase activity was blocked by incubating sections with $3 \% \mathrm{H}_{2} \mathrm{O}_{2}$ in methanol for $15 \mathrm{~min}$. Then, normal goat serum (Sigma) was added to block non-specific interactions of the tissue with the primary antibody used. The tissue sections were then incubated with a rabbit polyclonal antibody for human Ki67 (1:100; Dako) for $2 \mathrm{~h}$, and for $1 \mathrm{~h}$ with secondary antibody goat anti-rabbit (1:200; Dako) conjugated to alkaline phosphatase at room temperature in a humid chamber. Apoptosis was evaluated in parallel sections by terminal deoxynucleotidyl transferase-mediated nick end labelling analysis using an apoptosis assay kit (Beyotime Institute of Biotechnology) according to the manufacturer's instructions $^{(37)}$. After visualisation with diaminobenzidine, cell nuclei were counterstained with haematoxylin in the tissue sections.

The number of positive cells was counted from ten random microscope fields per section at $100 \times$ magnification by a Nikon morphometric system (Nikon Corporation). Apoptosis index (AI) and proliferation index (PI) were defined as the ratio of single-stranded DNA-positive nuclei or Ki67-positive nuclei to total nuclei multiplied by 100 , respectively. The ratio of AI:PI was calculated by dividing the $\mathrm{AI}$ by the $\mathrm{PI}^{(38)}$.

\section{Caspase-3 activity assay}

The mucosal caspase- 3 activity in jejunum was determined by the colorimetric assay using a commercial kit (Beyotime Institute of Biotechnology) based on the ability of caspase- 3 to change acetyl-Asp-Glu-Val-Asp $p$-nitroanilide into a yellow formosan product $p$-nitroanilides ${ }^{(39)}$. The relative activity of caspase-3 was normalised to total proteins, and expressed as fold change relative to Normal control piglets ${ }^{(39)}$.

\section{Protein immunoblot analysis}

Jejunal mucosa stored in liquid $\mathrm{N}_{2}$ was ground into powder, followed by centrifugation ${ }^{(13)}$. Protein concentration in the supernatant was determined using Bradford's method ${ }^{(40)}$. Equal amounts of protein $(50 \mu \mathrm{g}$ per lane) were subjected to SDS-PAGE (Mini-PROTEAN II electrophoresis system; Bio-Rad Laboratory) ${ }^{(41)}$, and transferred on to an activated polyvinylidene difluoride membrane. For immunostaining, membranes were incubated with appropriate primary antibodies generated in rabbit (Cell Signaling Technology), and then incubated with horseradish peroxidase-conjugated secondary antibodies (ZDR-5306, Goat anti-rabbit; Zhongshan Goldenbridge) at a dilution of 1:5000. Blots were developed using an enhanced chemiluminescence kit (ECL), and visualised on Kodak-X-Omat film in a DuPont Lighting plus intensifying screen. The intensity of the protein bands was quantified by a computerised densitometry method in Adobe Photoshop software (Adobe). The polyclonal antibodies for phospho-Akt (Ser ${ }^{473}$ ) (no. 4058, 1:1000), total Akt (no. 9272 , 1:1000), phospho-mTOR (Ser ${ }^{2448}$ ) (no. 2971, 1:1000), total mTOR (no. 2983, 1:1000), phospho-S6K1 ( Thr $^{389}$ ) (no. 9234 , 1:1000), total S6K1 (no. 2708, 1:1000) were used in this study. The ratio of phosphorylated form to total protein was presented next to the blots.

\section{Statistical analysis}

Normal control, IUGR control and IUGR + Arg were paired within litters, and this set was a randomised block design, where blocks were litters. Hence, comparisons between any two groups were made using the paired $t$ test $^{(42)}$. For the BW data, there were two repeated measures. Modelling of repeated records was done using the MIXED procedure.

\footnotetext{
chamber. Apoptosis was evaluated in parallel sections by
} 
Table 2. Body weight (BW) in Normal and intra-uterine growth retarded (IUGR) piglets ${ }^{\star}$ from 7 to $14 \mathrm{~d}$ of age, reared on a bottle-feeding system

(Mean values with their standard errors, $n 6$ )

\begin{tabular}{|c|c|c|c|c|c|c|c|c|c|}
\hline \multirow[b]{2}{*}{ Items } & \multicolumn{2}{|c|}{ Normal† } & \multicolumn{2}{|c|}{ IUGR† } & \multicolumn{2}{|c|}{ IUGR + Argł } & \multicolumn{3}{|c|}{$P$} \\
\hline & Mean & SEM & Mean & SEM & Mean & SEM & Group & Day & Group $\times$ Day \\
\hline $7 \mathrm{~d}(\mathrm{~kg})$ & $3 \cdot 37^{\mathrm{a}}$ & 0.12 & $2 \cdot 09^{b}$ & 0.13 & $2 \cdot 18^{b}$ & 0.17 & & & \\
\hline $14 \mathrm{~d}(\mathrm{~kg})$ & $4 \cdot 88^{a}$ & 0.06 & $3.03^{c}$ & 0.15 & $3.69^{b}$ & 0.16 & & & \\
\hline LS means $(\mathrm{kg})$ & $4 \cdot 12^{\mathrm{a}}$ & 0.11 & $2.59^{c}$ & 0.12 & $2 \cdot 94^{b}$ & 0.11 & $<0.001$ & $<0.001$ & 0.004 \\
\hline
\end{tabular}

Arg, L-arginine; LS, least square.

$a, b, c$ Mean values within a row with unlike superscript letters were significantly different $(P<0 \cdot 05)$.

${ }^{*}$ A piglet was defined as IUGR when its birth weight was 2 SD below the mean BW of the total population; when its birth weight was within

$1 \mathrm{SD}$ of the mean BW, it was defined as Normal.

† Piglets fed the control diet containing $1.23 \%$ L-alanine (isonitrogenous control).

$\ddagger$ Piglets fed the Arg diet supplemented with $0.60 \%$ Arg.

Effects were compared using the CONTRAST and LSMEANS statement in the repeated MIXED analysis. The diarrhoea rate was analysed by the $\chi^{2}$ test. Pearson correlation coefficients were determined (CORR procedure) between the Arg supplementation levels and all the parameters measured in IUGR piglets. All statistical analyses were performed using SAS (SAS Institute, Inc.). Probability values < $<.05$ were considered as significant difference. Data are presented as means with their standard errors.

\section{Results}

\section{Milk intake and growth performance}

In the present study, repeated analysis showed that, group, day, and group and day interaction had significant effect $(P<0.05)$ on $\mathrm{BW}$ in piglets from 7 to $14 \mathrm{~d}$ of age (Table 2$).$ The BW of IUGR piglets was lower $(P<0.05)$ than that of Normal piglets. IUGR piglets treated by Arg had a higher $(P<0.05) \mathrm{BW}$ compared with IUGR control piglets. However, it was still lower $(P<0.05)$ than that of Normal piglets. These were consistent with the results of BW at $14 \mathrm{~d}$ of age. A positive correlation was established between $14 \mathrm{~d}$ BW of IUGR piglets and Arg-supplemented levels ( $r 0 \cdot 70, P=0 \cdot 017)$. Piglets in the IUGR group showed decreased daily weight gain, and daily DM intake $(P<0.05)$ in comparison to the Normal control group (Table 3). Arg treatment increased $(P<0.05)$ the daily weight gain and daily DM intake by $47 \cdot 3$ and $21.4 \%$, respectively, and decreased the diarrhoea rate by $61.5 \%$ compared with IUGR piglets fed the control diet $(P<0.05)$. For daily weight gain and daily DM intake, positive correlations with Arg supplementation in IUGR piglets from 7 to $14 \mathrm{~d}$ of age were found $(P<0.05)$, and an inverse correlation between diarrhoea rate and Arg supplementation in IUGR piglets was observed $(P<0.05)$.

\section{Small intestine weight, length and mucosa weight}

IUGR decreased $(P<0.05)$ the entire SI weight:length ratio by $29 \cdot 4 \%$ compared with Normal piglets at $14 \mathrm{~d}$ of age. The entire SI length $(-12 \cdot 1 \%, P=0 \cdot 403)$, the SI weight $(-35 \cdot 0 \%$, $P=0.065)$, the mucosal weight $(-23.8 \%, P=0.266)$, the SI weight:BW ratio $(-17 \cdot 1 \%, P=0.063)$ and the mucosal weight:length ratio $(-17 \cdot 2 \%, P=0 \cdot 201)$ also showed a trend to be lower in IUGR piglets (Table 4). Dietary Arg increased $(P<0.05)$ the SI weight by $73 \cdot 2 \%$ and SI weight:length ratio by $62.4 \%$ in IUGR piglets, respectively, and did not differ ( $P=0.071$ and $0 \cdot 155$, respectively) from those of Normal piglets. Interestingly, the SI weight:BW ratio, mucosal weight and mucosal weight:length ratio of SI in IUGR piglets treated by Arg were increased $(P<0.05)$ by $43.3,87.9$ and $76.7 \%$ compared with IUGR piglets, and by 18.8 , 43.2 and $16.4 \%$

Table 3. Growth performance and diarrhoea rate in Normal and intra-uterine growth retarded (IUGR) piglets ${ }^{*}$ from 7 to $14 \mathrm{~d}$ of age, reared on a bottle-feeding system

(Mean values with their standard errors, $n 6$ )

\begin{tabular}{|c|c|c|c|c|c|c|c|c|c|c|c|}
\hline \multirow[b]{2}{*}{ Items } & \multicolumn{2}{|c|}{$\begin{array}{l}\text { Normalt } \\
\text { (Group A) }\end{array}$} & \multicolumn{2}{|c|}{$\begin{array}{l}\text { IUGR† } \\
\text { (Group B) }\end{array}$} & \multicolumn{2}{|c|}{$\begin{array}{l}\text { IUGR }+ \text { Argf } \\
\text { (Group C) }\end{array}$} & \multicolumn{3}{|c|}{$P$} & \multicolumn{2}{|c|}{ Correlation§ } \\
\hline & Mean & SEM & Mean & SEM & Mean & SEM & $A v . B$ & B v. C & C v. A & $r$ & $P$ \\
\hline $\operatorname{ADG}(g / d)$ & $216^{a}$ & 16 & $146^{\mathrm{b}}$ & 20 & $216^{a}$ & 11 & 0.002 & 0.040 & 0.971 & 0.73 & 0.010 \\
\hline DMI (g/d) & $309^{a}$ & 9 & $193^{c}$ & 10 & $235^{\mathrm{b}}$ & 14 & $<0.001$ & 0.044 & 0.002 & 0.62 & 0.042 \\
\hline Diarrhoea rate (\%) & $19 \cdot 1^{\mathrm{b}}$ & $7 \cdot 1$ & $37 \cdot 1^{\mathrm{a}}$ & $7 \cdot 3$ & $14 \cdot 3^{b}$ & 3.7 & 0.033 & 0.040 & 0.067 & -0.70 & 0.016 \\
\hline
\end{tabular}

Arg, L-arginine; ADG, daily weight gain; DMI, daily DM intake.

a,b,c Mean values within a row with unlike superscript letters were significantly different $(P<0.05)$.

${ }^{*}$ A piglet was defined as IUGR when its birth weight was 2 SD below the mean body weight (BW) of the total population; when its birth weight was within 1 SD of the mean BW, it was defined as Normal.

†Piglets fed the control diet containing $1.23 \%$ L-alanine (isonitrogenous control).

$\ddagger$ Piglets fed the Arg diet supplemented with $0.60 \%$ Arg.

$\S$ Pearson correlation coefficients were determined in IUGR piglets supplemented with 0 and $0.60 \%$ Arg. 
Table 4. Length and weight of the entire small intestine (SI), SI mucosal weight in Normal and intra-uterine growth retarded (IUGR) piglets* at $14 \mathrm{~d}$ of age, reared on a bottle-feeding system

(Mean values with their standard errors, $n 4$ )

\begin{tabular}{|c|c|c|c|c|c|c|c|c|c|c|c|}
\hline \multirow[b]{2}{*}{ Items } & \multicolumn{2}{|c|}{$\begin{array}{l}\text { Normalt } \\
\text { (Group A) }\end{array}$} & \multicolumn{2}{|c|}{$\begin{array}{l}\text { IUGR† } \\
\text { (Group B) }\end{array}$} & \multicolumn{2}{|c|}{$\begin{array}{l}\text { IUGR }+ \text { Argf } \\
\text { (Group C) }\end{array}$} & \multicolumn{3}{|c|}{$P$} & \multicolumn{2}{|c|}{ Correlation§ } \\
\hline & Mean & SEM & Mean & SEM & Mean & SEM & A v. B & B v. C & C v. A & $r$ & $P$ \\
\hline Length (cm) & 571 & 20 & 502 & 43 & 554 & 16 & 0.403 & 0.152 & 0.736 & 0.42 & 0.299 \\
\hline Intestinal wt (g) & $112 \cdot 6^{a, b}$ & 3.6 & $73 \cdot 2^{b}$ & $16 \cdot 8$ & $126 \cdot 7^{\mathrm{a}}$ & 5.5 & 0.065 & 0.029 & 0.071 & 0.78 & 0.023 \\
\hline Mucosal wt (g) & $30 \cdot 4^{\mathrm{b}}$ & 1.4 & $23 \cdot 2^{\mathrm{b}}$ & $6 \cdot 2$ & $43 \cdot 5^{\mathrm{a}}$ & $2 \cdot 2$ & 0.266 & 0.035 & 0.001 & 0.78 & 0.021 \\
\hline Intestinal wt:BW (\%) & $2 \cdot 74^{\mathrm{b}}$ & 0.14 & $2 \cdot 27^{\mathrm{b}}$ & 0.26 & $3.25^{\mathrm{a}}$ & 0.13 & 0.063 & 0.033 & 0.016 & 0.81 & 0.015 \\
\hline Mucosal wt:BW (\%) & $0.74^{\mathrm{b}}$ & 0.05 & $0.71^{a, b}$ & 0.11 & $1 \cdot 12^{\mathrm{a}}$ & 0.09 & 0.717 & 0.058 & 0.014 & 0.76 & 0.030 \\
\hline Intestinal wt:L (g/m) & $19 \cdot 9^{a}$ & 1.5 & $14 \cdot 1^{\mathrm{b}}$ & $2 \cdot 4$ & $22 \cdot 9^{\mathrm{a}}$ & 0.7 & 0.016 & 0.038 & 0.155 & 0.82 & 0.013 \\
\hline Mucosal wt:L (g/m) & $5 \cdot 4^{\mathrm{b}}$ & 0.4 & $4.5^{\mathrm{b}}$ & 1.0 & $7.9^{a}$ & 0.4 & 0.201 & 0.042 & 0.023 & 0.80 & 0.017 \\
\hline
\end{tabular}

Arg, L-arginine; BW, body weight; L, length.

$\mathrm{a}, \mathrm{b}$ Mean values within a row with unlike superscript letters were significantly different $(P<0.05)$.

${ }^{*}$ A piglet was defined as IUGR when its birth weight was 2 SD below the mean BW of the total population; when its birth weight was within 1 SD of the mean BW, it was defined as Normal.

†Piglets fed the control diet containing $1 \cdot 23 \%$ L-alanine (isonitrogenous control)

$\ddagger$ Piglets fed the Arg diet supplemented with $0.60 \%$ Arg.

$\S$ Pearson correlation coefficients were determined in IUGR piglets supplemented with 0 and $0.60 \% \mathrm{Arg}$.

compared with Normal piglets, respectively. The mucosal weight:BW ratio in IUGR piglets fed with the Arg diet was also elevated compared with both IUGR piglets $(P=0.058)$ and Normal piglets $(P<0.05)$ fed the control diet. In this study, as expected, all SI growth parameters except length measured were positively correlated $(P<0.05)$ with Arg supplementation in IUGR piglets. These results suggest that dietary supplementation of Arg improves the growth of SI mucosa in IUGR piglets.

\section{Intestinal morphology}

Measurements of villus height, crypt depth, villus height: villus width ratio, and villus height:crypt depth ratio did not differ $(P>0.05)$ in the duodenum of piglets among all groups (Table 5). However, the villus width in both IUGR and IUGR + Arg piglets was lower $(P<0.05)$ than that of Normal piglets. Both proximal and distal jejunal villus height, villus height:villus width ratio and villus height:crypt depth ratio were increased $(P<0.05)$ by Arg supplementation in IUGR piglets, and had no difference $(P>0.05)$ compared with Normal piglets. No significant difference $(P>0.05)$ was observed in crypt depth and villus width of both the proximal and distal jejunum. In the ileum, the decreased $(P<0 \cdot 05)$ villus height in IUGR piglets was recovered $(P<0.05)$ by Arg supplementation. However, the ileal crypt depth, villus width, villus height:villus width ratio and villus height:crypt depth ratio were not affected ( $P>0.05)$ by Arg supplementation in IUGR piglets. Moreover, Arg supplementation in IUGR piglets was positively correlated $(P<0.05)$ with villus height and villus width of the distal jejunum and ileum, proximal jejunal villus width and distal jejunal villus height:crypt depth ratio, respectively.

\section{Apoptosis and proliferation}

In the present study, the apoptotic cells were located in the upper region of the villus, while the proliferating cells were distributed around the lower part of the intestinal crypt in 14-d-old piglets (data not shown). These were consistent with previous studies ${ }^{(36,37)}$. IUGR showed a trend to decrease $(P=0.059)$ the PI in the distal jejunal mucosa, increased $(P<0.05)$ the AI by $32 \cdot 7 \%$, and the ratio of AI to PI by $44 \cdot 1 \%$ compared with Normal piglets, respectively (Table 6). Dietary supplementation with Arg decreased $(P<0.05)$ AI by $43.0 \%$, the ratio of AI:PI by $45.3 \%$ in IUGR piglets, and did not differ compared to Normal piglets $(P=0.077$ and 0.118 , respectively). Arg supplementation in IUGR piglets was inversely correlated $(P<0.05)$ with both $\mathrm{AI}$ and the ratio of $\mathrm{AI}: \mathrm{PI}$ The relative activity of caspase- 3 in the distal jejunal mucosa was also decreased $(P<0.05)$ by Arg supplementation in IUGR piglets. PI in Arg-treated IUGR piglets did not differ from IUGR piglets and Normal piglets $(P=0.309$ and 0.268 , respectively).

\section{Small intestine mucosal concentration of amino acids}

The concentrations of amino acids in SI mucosa of piglets at $14 \mathrm{~d}$ of age, including histidine, isoleucine, leucine, lysine, methionine, phenylalanine, threonine, tryptophane, valine, aspartate, glutamate, glutamine, alanine, asparagines, cystine, glycine, serine and tyrosine did not differ $(P>0.05)$ among the three groups (data not shown), and no correlations $(P>0.05)$ with Arg supplementation in IUGR piglets were found. However, IUGR piglets revealed decreased $(P<0.05)$ concentrations of Arg, citrulline (Cit), ornithine (Orn) and proline (Pro) in SI mucosa compared with Normal piglets (Table 7). Dietary Arg supplementation in IUGR piglets increased $(P<0.05)$ the concentrations of Arg, Cit and Pro by $10 \cdot 5,21.6$ and $9 \cdot 6 \%$, respectively. The concentrations of these amino acids in IUGR + Arg piglets were similar to those of Normal piglets (Arg, $P=0.090$; Cit, $P=0.852$ and Pro, $P=0.605)$. Mucosal concentrations of Arg, Cit and Pro were positively correlated $(P<0.05)$ with Arg supplementation in IUGR piglets, respectively. 
Table 5. Morphometric measurements of the duodenum, proximal jejunum, distal jejunum and ileum in Normal and intra-uterine growth retarded (IUGR) piglets* at $14 \mathrm{~d}$ of age, reared on a bottle-feeding system

(Mean values with their standard errors, $n 4$ )

\begin{tabular}{|c|c|c|c|c|c|c|c|c|c|c|c|}
\hline \multirow[b]{2}{*}{ Items } & \multicolumn{2}{|c|}{$\begin{array}{l}\text { Normal† } \\
\text { (Group A) }\end{array}$} & \multicolumn{2}{|c|}{$\begin{array}{c}\text { IUGR† } \\
\text { (Group B) }\end{array}$} & \multicolumn{2}{|c|}{$\begin{array}{l}\text { IUGR + Argf } \\
\text { (Group C) }\end{array}$} & \multicolumn{3}{|c|}{$P$} & \multicolumn{2}{|c|}{ Correlation§ } \\
\hline & Mean & SEM & Mean & SEM & Mean & SEM & A v $v$ B & B v. C & $C v . A$ & $r$ & $P$ \\
\hline \multicolumn{12}{|l|}{ Duodenum } \\
\hline Villus ht $(\mu \mathrm{m})$ & 813 & 40 & 698 & 50 & 829 & 67 & 0.329 & 0.446 & 0.781 & 0.58 & 0.173 \\
\hline Villus width ( $\mu \mathrm{m})$ & $204^{\mathrm{a}}$ & 5 & $157^{\mathrm{b}}$ & 4 & $163^{\mathrm{b}}$ & 3 & 0.005 & 0.618 & 0.032 & 0.54 & 0.207 \\
\hline Crypt depth $(\mu \mathrm{m})$ & 124 & 2 & 103 & 5 & 130 & 13 & 0.111 & 0.258 & 0.120 & 0.47 & 0.288 \\
\hline HWR & 6.55 & $0 \cdot 31$ & 6.77 & 0.46 & 6.55 & 0.80 & 0.795 & 0.803 & 0.414 & 0.60 & 0.157 \\
\hline VCR & 3.98 & $0 \cdot 13$ & 4.46 & 0.42 & $5 \cdot 13$ & 0.51 & 0.471 & 0.581 & 0.176 & $-0 \cdot 10$ & 0.833 \\
\hline \multicolumn{12}{|l|}{ Proximal jejunum } \\
\hline Villus ht $(\mu \mathrm{m})$ & $848^{a, b}$ & 21 & $639^{\mathrm{b}}$ & 93 & $958^{\mathrm{a}}$ & 48 & 0.076 & 0.024 & 0.055 & 0.75 & 0.052 \\
\hline Villus width $(\mu \mathrm{m})$ & 120 & 6 & 130 & 9 & 139 & 23 & 0.712 & 0.502 & 0.547 & 0.77 & 0.042 \\
\hline Crypt depth $(\mu \mathrm{m})$ & 98 & 1 & 107 & 12 & 106 & 9.99 & 0.872 & 0.806 & 0.537 & 0.19 & 0.687 \\
\hline HWR & $8 \cdot 66^{a, b}$ & $0 \cdot 10$ & $6 \cdot 04^{b}$ & 0.78 & $9 \cdot 26^{a}$ & 1.14 & 0.108 & 0.047 & 0.621 & -0.02 & 0.966 \\
\hline VCR & $7 \cdot 11^{\mathrm{a}}$ & 0.51 & $4.89^{b}$ & 0.59 & $7 \cdot 20^{\mathrm{a}}$ & 1.05 & 0.034 & 0.070 & 0.950 & 0.74 & 0.060 \\
\hline \multicolumn{12}{|l|}{ Distal jejunum } \\
\hline Villus ht $(\mu \mathrm{m})$ & $773^{a, b}$ & 10 & $511^{\mathrm{b}}$ & 118 & $1086^{a}$ & 140 & 0.148 & 0.020 & 0.251 & 0.78 & 0.038 \\
\hline Villus width $(\mu \mathrm{m})$ & 110 & 16 & 108 & 12 & 110 & 9 & 0.925 & 0.716 & 0.603 & 0.80 & 0.031 \\
\hline Crypt depth $(\mu \mathrm{m})$ & 87 & 4 & 90 & 16 & 125 & 12 & 0.845 & 0.113 & 0.145 & 0.05 & 0.920 \\
\hline HWR & $8.93^{a, b}$ & 0.30 & $5 \cdot 64^{\mathrm{b}}$ & 0.86 & $8 \cdot 63^{a}$ & 0.56 & 0.055 & 0.026 & 0.976 & 0.63 & 0.131 \\
\hline VCR & $7 \cdot 29^{a, b}$ & 0.92 & $4 \cdot 60^{b}$ & 0.75 & $9 \cdot 78^{a}$ & 0.73 & 0.248 & 0.011 & 0.251 & 0.81 & 0.029 \\
\hline \multicolumn{12}{|l|}{ Ileum } \\
\hline Villus ht $(\mu \mathrm{m})$ & $903^{a}$ & 40 & $599^{b}$ & 79 & $934^{\mathrm{a}}$ & 41 & 0.008 & 0.048 & 0.575 & 0.85 & 0.016 \\
\hline Villus width $(\mu \mathrm{m})$ & 124 & 15 & 101 & 8 & 128 & 6 & 0.190 & 0.250 & 0.881 & 0.83 & 0.020 \\
\hline Crypt depth $(\mu \mathrm{m})$ & 113 & 10 & 105 & 11 & 135 & 3 & 0.705 & 0.155 & 0.256 & 0.74 & 0.059 \\
\hline HWR & 8.10 & 0.79 & $5 \cdot 71$ & 0.46 & 6.93 & 0.13 & 0.060 & 0.184 & 0.217 & 0.69 & 0.085 \\
\hline VCR & 7.49 & 1.00 & 6.08 & 1.09 & $7 \cdot 32$ & 0.13 & 0.402 & 0.636 & 0.880 & 0.71 & 0.076 \\
\hline
\end{tabular}

Arg, L-arginine; HWR, villus height:villus width ratio; VCR, villus height:crypt depth ratio.

${ }^{a}, \mathrm{~b}$ Mean values within a row with unlike superscript letters were significantly different $(P<0.05)$.

* A piglet was defined as IUGR when its birth weight was 2 SD below the mean body weight (BW) of the total population; when its birth weight was within 1 SD of the mean BW, it was defined as Normal.

†Piglets fed the control diet containing $1.23 \%$ L-alanine (isonitrogenous control).

$\ddagger$ Piglets fed the Arg diet supplemented with $0.60 \%$ Arg.

$\S$ Pearson correlation coefficients were determined in IUGR piglets supplemented with 0 and $0.60 \% \mathrm{Arg}$

Insulin and insulin growth factor 1 level in small intestine

\section{mucosa}

In comparison with Normal piglets, IUGR decreased $(P<0.05)$ the levels of insulin and IGF- 1 by $23 \cdot 2$ and $24 \cdot 2 \%$ in terms of per g wet mucosa and by 19.8 and $20.6 \%$ when normalised to the total protein level in mucosa (Table 8). In Arg-treated
IUGR piglets, the levels of insulin in terms of per $\mathrm{g}$ wet mucosa and per g mucosal protein were increased $(P<0.05)$ by $27 \cdot 0$ and $24 \cdot 4 \%$ compared with IUGR control piglets. Similarly, the IGF-1 levels showed an increased trend $(P=0.173$ and 0.222 , respectively). For insulin levels, the correlations with Arg supplementation in IUGR piglets were positive $(P<0.05)$, but no correlations $(P>0.05)$ between

Table 6. Apoptosis and proliferation of small intestine mucosa in Normal and intra-uterine growth retarded (IUGR) piglets * at $14 \mathrm{~d}$ of age, reared on a bottle-feeding system

(Mean values with their standard errors, $n 4$ )

\begin{tabular}{|c|c|c|c|c|c|c|c|c|c|c|c|}
\hline \multirow[b]{2}{*}{ Items } & \multicolumn{2}{|c|}{$\begin{array}{l}\text { Normalt } \\
\text { (Group A) }\end{array}$} & \multicolumn{2}{|c|}{$\begin{array}{l}\text { IUGR† } \\
\text { (Group B) }\end{array}$} & \multicolumn{2}{|c|}{$\begin{array}{l}\text { IUGR + Argf } \\
\text { (Group C) }\end{array}$} & \multicolumn{3}{|c|}{$P$} & \multicolumn{2}{|c|}{ Correlation§ } \\
\hline & Mean & SEM & Mean & SEM & Mean & SEM & A v. B & B v. C & $C v \cdot A$ & $r$ & $P$ \\
\hline $\mathrm{Al}(\%)$ & $1.42^{\mathrm{b}}$ & 0.14 & $1 \cdot 89^{a}$ & 0.16 & $1.08^{\mathrm{b}}$ & 0.10 & 0.002 & 0.007 & 0.077 & -0.87 & 0.005 \\
\hline PI (\%) & $67 \cdot 20$ & 2.07 & 61.98 & 0.39 & 63.45 & 0.83 & 0.059 & 0.309 & 0.268 & 0.55 & 0.160 \\
\hline Al:PI (\%) & $2 \cdot 11^{b}$ & 0.18 & $3.04^{\mathrm{a}}$ & 0.24 & $1.70^{\mathrm{b}}$ & 0.15 & 0.005 & 0.004 & 0.118 & -0.89 & 0.003 \\
\hline Caspase-3 (\%) & $100^{a, b}$ & 9 & $127^{\mathrm{a}}$ & 7 & $104^{b}$ & 8 & 0.111 & 0.018 & 0.585 & -0.74 & 0.094 \\
\hline
\end{tabular}

Arg, L-arginine; Al, apoptosis index; PI, proliferation index.

a,b Mean values within a row with unlike superscript letters were significantly different $(P<0.05)$

${ }^{*}$ A piglet was defined as IUGR when its birth weight was 2 SD below the mean body weight (BW) of the total population; when its birth weight was within 1 SD of the mean BW, it was defined as Normal.

†Piglets fed the control diet containing $1.23 \%$ L-alanine (isonitrogenous control).

¥Piglets fed the Arg diet supplemented with $0.60 \%$ Arg.

$\S$ Pearson correlation coefficients were determined in IUGR piglets supplemented with 0 and $0.60 \%$ Arg. 
Table 7. Amino acid concentrations of small intestine mucosa in Normal and intra-uterine growth retarded (IUGR) piglets ${ }^{\star}$ at $14 \mathrm{~d}$ of age, reared on a bottle-feeding system

(Mean values with their standard errors, $n 4$ )

\begin{tabular}{|c|c|c|c|c|c|c|c|c|c|c|c|}
\hline \multirow[b]{2}{*}{ Items } & \multicolumn{2}{|c|}{$\begin{array}{l}\text { Normal† } \\
\text { (Group A) }\end{array}$} & \multicolumn{2}{|c|}{$\begin{array}{l}\text { IUGR† } \\
\text { (Group B) }\end{array}$} & \multicolumn{2}{|c|}{$\begin{array}{c}\text { IUGR + Argf } \\
\text { (Group C) }\end{array}$} & \multicolumn{3}{|c|}{$P$} & \multicolumn{2}{|c|}{ Correlation§ } \\
\hline & Mean & SEM & Mean & SEM & Mean & SEM & $A v . B$ & B v. C & C v. A & $r$ & $P$ \\
\hline $\operatorname{Arg}(\mathrm{nmol} / \mathrm{g}$ wet $\mathrm{wt})$ & $2151^{a}$ & 17 & $1994^{\mathrm{b}}$ & 13 & $2202^{a}$ & 25 & 0.006 & 0.003 & 0.090 & 0.95 & $<0.001$ \\
\hline Cit (nmol/g wet wt) & $495^{\mathrm{a}}$ & 13 & $410^{\mathrm{b}}$ & 5 & $499^{a}$ & 10 & 0.010 & 0.006 & 0.852 & 0.96 & $<0.001$ \\
\hline Pro (nmol/g wet wt) & $5546^{\mathrm{a}}$ & 103 & $5117^{\mathrm{b}}$ & 46 & $5610^{a}$ & 181 & 0.005 & 0.040 & 0.605 & 0.52 & 0.188 \\
\hline Orn (nmol/g wet wt) & $169^{a}$ & 3 & $151^{\mathrm{b}}$ & 4 & $162^{a, b}$ & 6 & 0.012 & 0.276 & 0.450 & 0.73 & 0.039 \\
\hline Ala (nmol/g wet wt) & 8165 & 392 & 8050 & 337 & 8177 & 169 & 0.420 & 0.743 & 0.979 & 0.14 & 0.748 \\
\hline
\end{tabular}

Arg, L-arginine; Cit, citrulline; Orn, ornithine; Pro, proline; Ala, alanine.

a,b Mean values within a row with unlike superscript letters were significantly different $(P<0.05)$

${ }^{*}$ A piglet was defined as IUGR when its birth weight was 2 SD below the mean body weight (BW) of the total population; when its birth weight was within 1 SD of the mean BW, it was defined as Normal.

$\dagger$ Piglets fed the control diet containing $1 \cdot 23 \%$ Ala (isonitrogenous control).

$\ddagger$ Piglets fed the Arg diet supplemented with $0.60 \%$ Arg.

$\S$ Pearson correlation coefficients were determined in IUGR piglets supplemented with 0 and $0.60 \%$ Arg.

Arg supplementation and IGF-1 levels were observed. Moreover, the levels of insulin and IGF-1 in IUGR + Arg piglets were similar $(P>0.05)$ with Normal piglets fed the control diet at $14 \mathrm{~d}$ of age.

\section{Phosphorylation levels of Akt, mammalian target of rapamycin and p70 56 kinase}

Results of Western blots showed that IUGR decreased $(P<0.05)$ the phosphorylation of Akt on $\operatorname{Ser}^{473}$ by $34.1 \%$, the phosphorylation of mTOR on $\operatorname{Ser}^{2448}$ by $37.5 \%$ and the phosphorylation of $\mathrm{S} 6 \mathrm{~K} 1$ on $\mathrm{Thr}^{389}$ by $27 \cdot 7 \%$ in jejunal mucosa compared with Normal piglets at $14 \mathrm{~d}$ of age (Fig. 1). Dietary supplementation with $0.60 \%$ Arg increased $(P<0.05)$ the phosphorylation of Akt by $47 \cdot 7 \%$ and the phosphorylation of mTOR by $61.9 \%$ in IUGR piglets, and restored them to the levels in Normal BW piglets $(P=0.673$ and 0.899 , respectively). As expected, the phosphorylation levels of Akt and mTOR were positively correlated with Arg supplementation in IUGR piglets $(r 0.93, P<0.05$ and $r 0.90, P<0.05$, respectively). In contrast, the phosphorylation of S6K1 was not affected $(P=0 \cdot 116)$ by Arg supplementation in IUGR piglets.
No correlation between phosphorylation of S6K1 and Arg supplementation in IUGR piglets was observed $(r 0.70, P=0.052)$

\section{Discussion}

IUGR is a prevalent pathological phenomenon both in animals and in humans ${ }^{(2,6)}$. The neonatal pig has been well established as an ideal model system for investigating the development of the gastrointestinal tract in human neonates ${ }^{(6,18,23)}$. Studies in the pig model have shown that IUGR could negatively affect birth weight, neonatal survivability, gastrointestinal tract development and postnatal growth ${ }^{(2,6)}$. In both children and young pigs, Arg appears to be one of the most important amino acids for tissue growth $^{(12,43)}$ and SI development ${ }^{(25)}$. Sufficient Arg provision effectively improved the growth and protein synthesis in piglets at $14 \mathrm{~d}$ of age ${ }^{(9,13)}$. It also enhanced the migration of intestinal epithelial cells by phosphorylating S6K1 in vitro ${ }^{(25)}$. To our knowledge, this is the first study to determine the effects of dietary Arg supplementation on the growth performance and SI development through Akt and mTOR signals using IUGR piglets. However, the number of observations in the present study is limited ( $n$ 4).

Table 8. Protein concentration, insulin and insulin growth factor 1 (IGF-1) level in small intestine mucosa of Normal and intra-uterine growth retarded (IUGR) piglets* at $14 \mathrm{~d}$ of age, reared on a bottle-feeding system

(Mean values with their standard errors, $n 4$ )

\begin{tabular}{|c|c|c|c|c|c|c|c|c|c|c|c|}
\hline \multirow[b]{2}{*}{ Items } & \multicolumn{2}{|c|}{$\begin{array}{l}\text { Normal† } \\
\text { (Group A) }\end{array}$} & \multicolumn{2}{|c|}{$\begin{array}{l}\text { IUGR† } \\
\text { (Group B) }\end{array}$} & \multicolumn{2}{|c|}{$\begin{array}{l}\text { IUGR }+ \text { Argf } \\
\text { (Group C) }\end{array}$} & \multicolumn{3}{|c|}{$P$} & \multicolumn{2}{|c|}{ Correlation§ } \\
\hline & Mean & SEM & Mean & SEM & Mean & SEM & $A v \cdot B$ & B v. C & C v. A & $r$ & $P$ \\
\hline Protein (mg/g wet wt) & $40 \cdot 97$ & 0.86 & $39 \cdot 42$ & 1.69 & $40 \cdot 28$ & 1.42 & 0.236 & 0.085 & 0.447 & $0 \cdot 16$ & 0.711 \\
\hline Insulin (pmol/g wet wt) & $0.142^{\mathrm{a}}$ & 0.010 & $0.109^{b}$ & 0.003 & $0.139^{\mathrm{a}}$ & 0.004 & 0.049 & $<0.001$ & 0.819 & 0.94 & 0.001 \\
\hline Insulin (pmol/g prot) & $3.47^{\mathrm{a}}$ & 0.26 & $2 \cdot 79^{\mathrm{b}}$ & 0.12 & $3.47^{\mathrm{a}}$ & 0.14 & 0.040 & $<0.001$ & 0.981 & 0.84 & 0.009 \\
\hline IGF-1 (pmol/g wet wt) & $10 \cdot 71^{\mathrm{a}}$ & 0.85 & $8 \cdot 12^{b}$ & 0.56 & $9 \cdot 76^{a, b}$ & 0.65 & 0.003 & 0.173 & 0.450 & 0.61 & 0.105 \\
\hline IGF-1 (pmol/g protein) & $261.33^{\mathrm{a}}$ & $19 \cdot 27$ & $207.41^{\mathrm{b}}$ & 17.65 & $243 \cdot 06^{a, b}$ & 17.91 & 0.001 & 0.222 & 0.510 & 0.50 & 0.206 \\
\hline
\end{tabular}

Arg, L-arginine.

${ }^{\mathrm{a}, \mathrm{b}}$ Mean values within a row with unlike superscript letters were significantly different $(P<0.05)$

${ }^{*}$ A piglet was defined as IUGR when its birth weight was 2 SD below the mean body weight (BW) of the total population; when its birth weight was within 1 SD of the mean BW, it was defined as Normal.

†Piglets fed the control diet containing $1.23 \%$ L-alanine (isonitrogenous control).

¥ Piglets fed the Arg diet supplemented with $0.60 \%$ Arg.

§ Pearson correlation coefficients were determined in IUGR piglets supplemented with 0 and $0.60 \% \mathrm{Arg}$. 
(A)

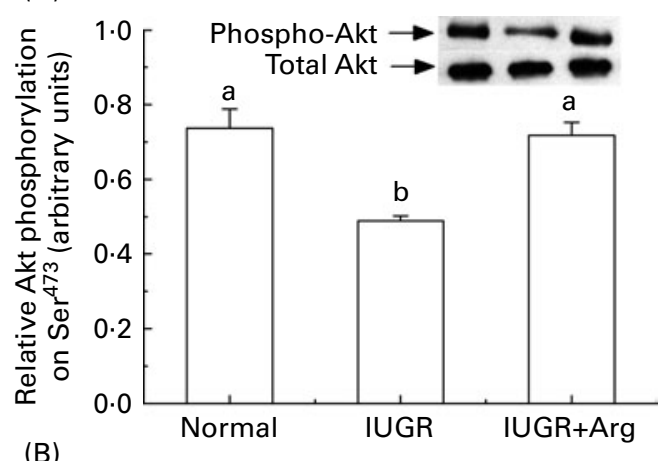

(B)

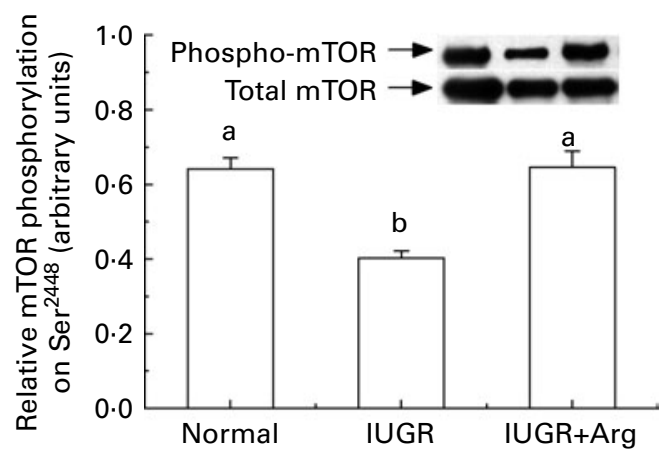

(C)

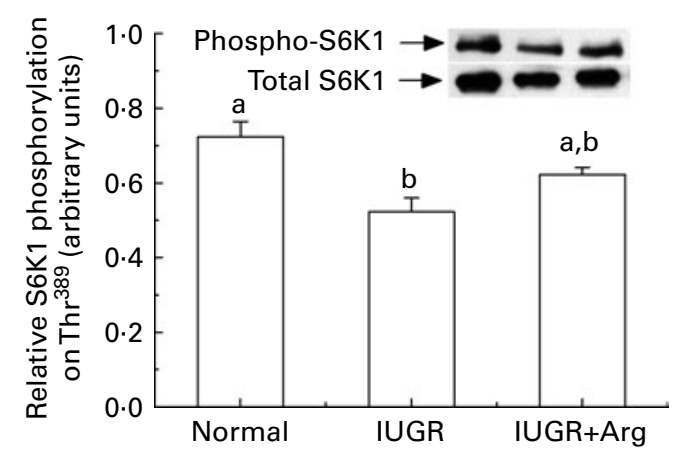

Fig. 1. Phosphorylation state of $(A) A k t,(B)$ mammalian target of rapamycin (mTOR) and (C) p70 S6 kinase (S6K1) in the jejunal mucosa of Normal and IUGR piglets at $14 \mathrm{~d}$ of age. A piglet was defined as intra-uterine growthretarded (IUGR) when its birth weight was 2 SD below the mean body weight (BW) of the total population; when its birth weight was within 1 SD of the mean BW, it was defined as Normal. Normal and IUGR piglets fed the control diet containing $1.23 \%$ L-alanine (isonitrogenous control). IUGR + L-arginine (Arg) piglets fed the Arg diet supplemented by $0.60 \%$ Arg between day 7 and day 14 after birth. At $14 \mathrm{~d}$ of age, $2 \mathrm{~h}$ after feeding, the jejunal mucosa was obtained from piglets. Akt phosphorylation on $\mathrm{Ser}^{473}$, mTOR phosphorylation on $\mathrm{Ser}^{2448}$ and S6K1 phosphorylation on $\mathrm{Thr}^{389}$ were measured by Western blot analysis using antibodies that recognise these proteins only when that residue was phosphorylated. Western blots are shown above each graph. Values for phosphorylation of each protein were normalised for total protein. Values are means, with their standard errors represented by vertical bars $(n 4)$. ${ }^{\mathrm{a}, \mathrm{b}}$ Mean values with unlike letters were significantly different $(P<0.05)$.

\section{Effect of L-arginine supplementation on body weight, growth and morphology of small intestine}

IUGR negatively affects birth weight and postnatal growth of animals ${ }^{(2)}$. This is consistent with our findings that IUGR decreased the growth performance of piglets from 7 to $14 \mathrm{~d}$ of age. The difference in daily DM intake we found is due to the change of $\mathrm{BW}$ and daily weight gain of piglets, because we fed them according to the BW, which was similar to the previous study ${ }^{(13)}$. Although the reduced growth and development of SI has been reported in newborn IUGR piglets ${ }^{(6-8,31)}$, few studies have investigated the effects of IUGR on the postnatal SI development. At $14 \mathrm{~d}$ of age, we found that IUGR decreased the SI weight per unit length as well as the ileal villus height. These results indicated that the negative effect of IUGR on pig gut development persists up to $14 \mathrm{~d}$ of age at least. This persistent effect may be one of the reasons for the long-term effect of IUGR on growth and development.

As an essential amino acid for suckling piglets, Arg deficiency is a major factor limiting maximum growth of milk-fed piglets ${ }^{(12)}$. The deficiency is even more prominent in IUGR piglets ${ }^{(10)}$. Consequently, dietary supplementation with $\operatorname{Arg}^{(9,13)}$ or activation of endogenous Arg synthesis ${ }^{(44)}$ is effective to increase Arg availability and growth performance in milk-fed piglets. In the present study, dietary supplementation with $0.60 \%$ Arg increased the growth traits of milk-fed IUGR piglets. This agrees with previous studies on milk-fed normal young pigs in the same period ${ }^{(9,13)}$, and is similar to the results found in 21-d-old weaned piglets $^{(27)}$.

The SI is a major site for Arg metabolism and synthesis ${ }^{(45)}$ and plays a critical role in maintaining Arg homeostasis in neonates $^{(12)}$. On the other hand, as an essential precursor for intestinal synthesis of glutathione, NO, polyamines, amino acids (Cit and Pro) ${ }^{(45)}$ and protein synthesis ${ }^{(24,46)}$, Arg plays an important role in intestinal functionality ${ }^{(47)}$. Recent research $^{(27)}$ has shown that dietary supplementation with $1 \%$ Arg enhanced intestinal growth in 21-d-old weaned piglets. We also showed that supplementation of $0.60 \% \mathrm{Arg}$ improved villus development and SI morphology in neonatal IUGR piglets. These effects were more evident in the jejunum, which was the primary site of nutrient absorption and amino acid metabolism in the $\mathrm{SI}^{(12)}$.

\section{Effect of $L$-arginine supplementation on the concentrations of amino acids in small intestine mucosa}

In neonatal mammals, SI enterocytes, the main place of endogenous Arg synthesis ${ }^{(48)}$, play a critical role in the homeostasis of $\operatorname{Arg}^{(11)}$. Arg is synthesised from glutamine, and Pro via the SI in humans and pigs ${ }^{(43)}$. In suckling piglets, most of the Cit synthesised in enterocytes is converted locally into $\operatorname{Arg}^{(11,43)}$. Arg degradation in the SI produces NO, polyamines, Pro, creatine and agmatine, with each having enormous biological importance ${ }^{(12,43)}$. In the present study, we found that IUGR decreased the concentration of Arg, and its metabolism referring to amino acids (including Cit, Orn and Pro). This is similar to the previous finding in skeletal muscle of fetal pigs as a result of maternal malnutrition ${ }^{(49)}$ and several other observations in the SI of humans and $\operatorname{pigs}^{(1,6,8,31)}$.

Dietary supplementation or infusion with Arg elevated the plasma Arg concentrations in young piglets ${ }^{(9,13)}$ and 
humans ${ }^{(50)}$. The plasma concentrations of Cit and Orn were also increased ${ }^{(9,13)}$. Similarly, we found that the concentrations of Arg, Cit and Pro were increased in SI mucosa of IUGR piglets fed diets supplemented with Arg. However, as one of the major products of Arg catabolism in the mitochondria of enterocytes, the level of Orn was not significantly changed by Arg treatment. This may be due to the negligible arginase activity $^{(11)}$. The metabolism of Arg in SI is oriented to anabolism rather than catabolism in the enterocytes of neonatal and suckling piglets, which exhibits a net production of Arg in the enterocytes of suckling piglets ${ }^{(51)}$. The reduced Cit, a precursor of $\mathrm{Arg}^{(11)}$, has been shown as a biomarker of intestinal failure in infants and adults ${ }^{(52)}$. Therefore, the increased Cit in intestinal mucosa of IUGR piglets by Arg supplementation suggests the improvement of the SI, which is further confirmed by our morphological observations in this study.

\section{Effect of L-arginine supplementation on apoptosis and proliferation of enterocytes in small intestine}

Previous studies showed that within the SI, IUGR enhanced apoptosis in rats ${ }^{(3)}$ and reduced cell proliferation in newborn rabbits $^{(53)}$. In the present study, IUGR increased the AI and reduced the PI of enterocytes in piglets. This indicated that IUGR might affect intestinal growth and morphology through enhancing apoptosis and reducing proliferation in suckling piglets $^{(3,18)}$. The enhanced apoptosis of enterocytes may create transient leaking gaps on the intestinal epithelium, which provide bacteria with easy access to the lamina propria and often induce inflammatory responses and cause diarrhoea. This has been reported in necrotising enterocolitis ${ }^{(54)}$.

Arg plays an important role in improving intestinal absorption and gut recovery after injury ${ }^{(55)}$. We also found that a diet supplemented with Arg decreased apoptosis and the ratio of AI:PI in SI mucosa of IUGR piglets, suggesting that Arg protects the enterocytes probably via regulating apoptosis in the SI. Previous studies ${ }^{(24,46,56)}$ have demonstrated that Arg stimulates ex vivo intestinal cell apoptosis, proliferation and protein synthesis, while enhancing mTOR activity. Caspase3 , a protease activated by Bcl-2 and Bax protein, plays a key role in the apoptosis of enterocytes ${ }^{(57)}$. Its activity in the SI was elevated by IUGR in $\operatorname{rats}^{(3)}$. We found that, consistent with the results of apoptosis, Arg supplementation significantly reduced the activity of caspase- 3 in the SI of IUGR piglets. NO is synthesised from Arg by NO synthase in almost all mammalian cells. In IUGR infants, the production of NO was reduced due to the low availability of plasma Arg, which may be involved in the pathophysiology of necrotising enterocolitis ${ }^{(15)}$. A certain amount of $\mathrm{NO}$ is required for maintaining cellular functions in physiological conditions ${ }^{(58)}$. However, an excess production of NO or its toxic metabolite, $\mathrm{ONOO}^{-}$, may promote mucosal injury and gut barrier failure, possibly through the induction of enterocyte apoptosis by the activation of caspases and accumulation of $\mathrm{p} 53^{(54)}$. In this study, mucosal caspase- 3 activity and enterocyte apoptosis were reduced in the IUGR piglets treated by Arg, which indicated that the Arg-dependent production of NO was not too much impaired in SI mucosa.

\section{Effect of L-arginine supplementation on the levels of insulin and phosphorylated Akt}

Akt plays a critical role in promoting cell survival by inhibiting apoptosis ${ }^{(19,20)}$. Akt can be activated by insulin and various growth factors ${ }^{(19)}$ through phosphorylation sites at $\operatorname{Ser}^{473}$ and $\mathrm{Thr}^{308(59)}$. In the present study, the levels of insulin and the phosphorylated Akt were decreased in the SI mucosa of 14-d-old IUGR piglets, suggesting that the insulin-Akt pathway is affected by IUGR.

Arg is a potent stimulator of insulin secretion ${ }^{(60)}$. Dietary supplementation with Arg elevated the plasma insulin level in artificially reared Normal piglets at $14 \mathrm{~d}$ of age ${ }^{(9,13)}$. We also observed increased Arg concentration in the SI mucosa of IUGR piglets. However, blood glucose is a well-known factor contributing to insulin production ${ }^{(61)}$. In the present study, no difference was observed in the concentration of serum glucose (data not shown). In addition, only minimal metabolism of ingested glucose occurs in SI mucosa ${ }^{(62)}$. Consequently, the elevated mucosal insulin level in IUGR piglets was probably due to the increased dietary Arg supplementation. The elevated insulin level by Arg may enhance the activation of $\mathrm{Akt}^{(19)}$, which inhibits intestinal cell DNA fragmentation and reduces cell apoptosis ${ }^{(47)}$. We found that Arg increased the concentrations of insulin and phosphorylated Akt and consequently improved both the development and morphology of the SI in IUGR piglets, indicating an essential role for Arg in insulin-Akt-mediated cytoprotection.

\section{Effect of L-arginine supplementation on the phosphorylation of mammalian target of rapamycin and p70 S6 kinase in small intestine mucosa}

mTOR, a Ser/Thr protein kinase, controls protein synthesis, cell survival and proliferation ${ }^{(59,63)}$. In the present study, IUGR decreased the mTOR phosphorylation compared with the Normal piglets in SI mucosa. mTOR is phosphorylated at $\mathrm{Ser}^{2448}$ via the PI3 kinase-Akt pathway ${ }^{(21)}$. Meanwhile, mTOR is a sensor for amino acids to balance the availability of nutrients and cell growth ${ }^{(22)}$. In our study, decreased Akt activity and amino acid concentrations were observed in SI mucosa of IUGR piglets. This indicates the dual effects on inhibition of mTOR activity. Inhibition of mTOR inhibits the protein synthesis due to inhibition of its effector S6K1 and activation of 4E-binding protein 1 , an inhibitor of translation $^{(64)}$. S6K1 is a mitogen-activated Ser/Thr protein kinase that is required for cell growth and G1 cell cycle progression $^{(65)}$. We found a decreased S6K1 phosphorylation, which correlated with the reduced enterocyte proliferation in SI mucosa of IUGR piglets.

Recent studies ${ }^{(24,25)}$ have shown that Arg stimulates intestinal cell migration, and ex vivo intestinal protein synthesis by enhancing the mTOR signalling activity and activating S6K1 in rat intestinal epithelial cells. We also found that dietary Arg increased the level of phosphorylated mTOR in SI mucosa of IUGR piglets at $14 \mathrm{~d}$ of age, which is similar to the finding in skeletal muscle of Normal piglets ${ }^{(13)}$. mTOR activity can be stimulated by Akt-dependent ${ }^{(21)}$ and/or 
Akt-independent pathway (amino acids signal) ${ }^{(66)}$. In the present study, the levels of insulin, Arg metabolism referring to amino acids (including Cit, Orn and Pro), as well as phosphorylated Akt and mTOR in SI mucosa were all increased in IUGR piglets treated by Arg. These results indicate that the insulin-Akt pathway and amino acids signal may play important roles in regulating mTOR by Arg in SI mucosa. This regulation may be specific to SI mucosa, since it was not observed in the skeletal muscle of piglets ${ }^{(66)}$.

In conclusion, IUGR decreased growth and development of the SI, induced enterocyte apoptosis and reduced Akt and mTOR activities of SI mucosa in neonatal piglets. Arg supplementation improved SI development and reduced the apoptosis of enterocytes in IUGR piglets through enhancing Akt and mTOR signalling. Our findings provide important implications for treating IUGR piglets after birth by stimulating the intestinal development with dietary supplementation with Arg. However, further studies are needed to confirm the effects of Arg on the pathway regulating mTOR and its effectors in SI mucosa, as well as to identify the effects of long-term supplementation of Arg on growth and intestinal development in IUGR pigs or humans.

\section{Acknowledgements}

The present study was jointly supported by the National Natural Science Foundation of China (30771569 and 30972116) and the Youth Sci-Tech Innovation Fund, NAU (KJ08014). The authors thank W. Xu, Q. Dong and J. Wang for their assistance in sample collection and the raising of piglets. The contributions of each author to the study were as follows: L. Z., G. Z. and Z. L. participated in the experiments together with Y. W., who also performed the data analysis and wrote the manuscript. T. W. and W. L. designed and supervised the study, and revised the manuscript together with $\mathrm{H}$. A. The authors had no conflicts of interest in the research.

\section{References}

1. Rosenberg A (2008) The IUGR newborn. Semin Perinatol 32, 219-224.

2. Wu G, Bazer FW, Wallace JM, et al. (2006) Board-invited review: intrauterine growth retardation: implications for the animal sciences. J Anim Sci 84, 2316-2337.

3. Baserga M, Bertolotto C, Maclennan NK, et al. (2004) Uteroplacental insufficiency decreases small intestine growth and alters apoptotic homeostasis in term intrauterine growth retarded rats. Early Hum Dev 79, 93-105.

4. McMillen IC \& Robinson JS (2005) Developmental origins of the metabolic syndrome: prediction, plasticity, and programming. Physiol Rev 85, 571-633.

5. Valsamakis G, Kanaka-Gantenbein C, Malamitsi-Puchner A, et al. (2006) Causes of intrauterine growth restriction and the postnatal development of the metabolic syndrome. Ann N Y Acad Sci 1092, 138-147.

6. Wang T, Huo YJ, Shi F, et al. (2005) Effects of intrauterine growth retardation on development of the gastrointestinal tract in neonatal pigs. Biol Neonate $\mathbf{8 8}, 66-72$.
7. Wang J, Chen L, Li D, et al. (2008) Intrauterine growth restriction affects the proteomes of the small intestine, liver, and skeletal muscle in newborn pigs. J Nutr 138, 60-66.

8. Xu RJ, Mellor DJ, Birtles MJ, et al. (1994) Impact of intrauterine growth retardation on the gastrointestinal tract and the pancreas in newborn pigs. J Pediatr Gastroenterol Nutr 18, 231-240.

9. Kim SW, McPherson RL \& Wu G (2004) Dietary arginine supplementation enhances the growth of milk-fed young pigs. J Nutr 134, 625-630.

10. Wu G, Jaeger LA, Bazer FW, et al. (2004) Arginine deficiency in preterm infants: biochemical mechanisms and nutritional implications. J Nutr Biochem 15, 442-451.

11. Wu G, Davis PK, Flynn NE, et al. (1997) Endogenous synthesis of arginine plays an important role in maintaining arginine homeostasis in postweaning growing pigs. $J$ Nutr 127, 2342-2349.

12. Wu G, Knabe DA \& Kim SW (2004) Arginine nutrition in neonatal pigs. J Nutr 134, 2783S-2790S, discussion 2796S-2797S.

13. Yao K, Yin YL, Chu W, et al. (2008) Dietary arginine supplementation increases mTOR signaling activity in skeletal muscle of neonatal pigs. J Nutr 138, 867-872.

14. Vosatka RJ, Hassoun PM \& Harvey-Wilkes KB (1998) Dietary L-arginine prevents fetal growth restriction in rats. $\mathrm{Am} \mathrm{J}$ Obstet Gynecol 178, 242-246.

15. Richir MC, Siroen MP, van Elburg RM, et al. (2007) Low plasma concentrations of arginine and asymmetric dimethylarginine in premature infants with necrotizing enterocolitis. Br J Nutr 97, 906-911.

16. Mateo RD, Wu G, Bazer FW, et al. (2007) Dietary L-arginine supplementation enhances the reproductive performance of gilts. J Nutr 137, 652-656.

17. Guilloteau P, Zabielski R, Hammon HM, et al. (2010) Nutritional programming of gastrointestinal tract development. Is the pig a good model for man? Nutr Res Rev 23, 4-22.

18. Zabielski R, Godlewski MM \& Guilloteau P (2008) Control of development of gastrointestinal system in neonates. J Physiol Pharmacol 59, 35-54.

19. Franke TF, Kaplan DR \& Cantley LC (1997) PI3K: downstream AKTion blocks apoptosis. Cell 88, 435-437.

20. Cardone MH, Roy N, Stennicke HR, et al. (1998) Regulation of cell death protease caspase-9 by phosphorylation. Science 282, 1318-1321.

21. Nave BT, Ouwens M, Withers DJ, et al. (1999) Mammalian target of rapamycin is a direct target for protein kinase $\mathrm{B}$ : identification of a convergence point for opposing effects of insulin and amino-acid deficiency on protein translation. Biochem J 344, 427-431.

22. Dennis PB, Jaeschke A, Saitoh M, et al. (2001) Mammalian TOR: a homeostatic ATP sensor. Science 294, 1102-1105.

23. Murgas Torrazza R, Suryawan A, Gazzaneo MC, et al. (2010) Leucine supplementation of a low-protein meal increases skeletal muscle and visceral tissue protein synthesis in neonatal pigs by stimulating mTOR-dependent translation initiation. J Nutr 140, 2145-2152.

24. Rhoads JM, Chen W, Gookin J, et al. (2004) Arginine stimulates intestinal cell migration through a focal adhesion kinase dependent mechanism. Gut 53, 514-522.

25. Rhoads JM, Liu Y, Niu X, et al. (2008) Arginine stimulates cdx2-transformed intestinal epithelial cell migration via a mechanism requiring both nitric oxide and phosphorylation of p70 S6 kinase. J Nutr 138, 1652-1657. 
26. Ban H, Shigemitsu K, Yamatsuji T, et al. (2004) Arginine and leucine regulate p70 56 kinase and 4E-BP1 in intestinal epithelial cells. Int J Mol Med 13, 537-543.

27. Yao K, Guan S, Li T, et al. (2011) Dietary L-arginine supplementation enhances intestinal development and expression of vascular endothelial growth factor in weanling piglets. Br J Nutr 105, 703-709.

28. AOAC (2000) Official Methods of Analysis of AOAC International, 17th ed. Gaithersburg, MD: AOAC.

29. Shulman RJ (1990) Oral insulin increases small intestinal mass and disaccharidase activity in the newborn miniature pig. Pediatr Res 28, 171-175.

30. National Research Council (1998) Nutrient Requirements of Swine, 10th ed. Washington, DC: National Academy Press.

31. Zhong X, Wang T, Zhang X, et al. (2010) Heat shock protein 70 is upregulated in the intestine of intrauterine growth retardation piglets. Cell Stress Chaperones 15, 335-342.

32. Wang J, Chen L, Li P, et al. (2008) Gene expression is altered in piglet small intestine by weaning and dietary glutamine supplementation. J Nutr 138, 1025-1032.

33. Martin GR, Wallace LE \& Sigalet DL (2004) Glucagon-like peptide- 2 induces intestinal adaptation in parenterally fed rats with short bowel syndrome. Am J Physiol Gastrointest Liver Physiol 286, G964-G972.

34. Bidlingmeyer BA, Cohen SA \& Tarvin TL (1984) Rapid analysis of amino acids using pre-column derivatization. J Chromatogr 336, 93-104.

35. Wu G \& Knabe DA (1995) Arginine synthesis in enterocytes of neonatal pigs. Am J Physiol 269, R621-R629.

36. Danilenko DM, Ring BD, Tarpley JE, et al. (1995) Growth factors in porcine full and partial thickness burn repair. Differing targets and effects of keratinocyte growth factor, platelet-derived growth factor-BB, epidermal growth factor, and neu differentiation factor. Am J Pathol 147, 1261-1277.

37. Miyazawa K, Aso H, Kanaya T, et al. (2005) Apoptotic process of porcine intestinal $\mathrm{M}$ cells. Cell Tissue Res 323, 425-432.

38. Hong MY, Turner ND, Carroll RJ, et al. (2005) Differential response to DNA damage may explain different cancer susceptibility between small and large intestine. Exp Biol Med 230, 464-471.

39. Yin ST, Tang ML, Deng HM, et al. (2009) Epigallocatechin-3gallate induced primary cultures of rat hippocampal neurons death linked to calcium overload and oxidative stress. Naunyn Schmiedebergs Arch Pharmacol 379, 551-564.

40. Bradford MM (1976) A rapid and sensitive method for the quantitation of microgram quantities of protein utilizing the principle of protein-dye binding. Anal Biochem $\mathbf{7 2}$, $248-254$.

41. Laemmli UK (1970) Cleavage of structural proteins during the assembly of the head of bacteriophage T4. Nature 227, 680-685.

42. Dauncey MJ, Burton KA \& Tivey DR (1994) Nutritional modulation of insulin-like growth factor-I expression in early postnatal piglets. Pediatr Res 36, 77-83.

43. Wu G, Bazer FW, Davis TA, et al. (2009) Arginine metabolism and nutrition in growth, health and disease. Amino Acids 37, 153-168.

44. Frank JW, Escobar J, Nguyen HV, et al. (2007) Oral $N$-carbamylglutamate supplementation increases protein synthesis in skeletal muscle of piglets. J Nutr 137, 315-319.

45. Wu G (1998) Intestinal mucosal amino acid catabolism. J Nutr 128, 1249-1252.

46. Corl BA, Odle J, Niu X, et al. (2008) Arginine activates intestinal p70(S6k) and protein synthesis in piglet rotavirus enteritis. J Nutr 138, 24-29.
47. Rhoads JM \& Wu G (2009) Glutamine, arginine, and leucine signaling in the intestine. Amino Acids 37, 111-122.

48. Kim SW \& Wu G (2009) Regulatory role for amino acids in mammary gland growth and milk synthesis. Amino Acids 37, 89-95.

49. Wu GY, Bazer FW, Datta S, et al. (2008) Intrauterine growth retardation in livestock: implications, mechanisms and solutions. Arch Fur Tierzucht-Arch Anim Breed 51, 4-10.

50. Nagasaka H, Yorifuji T, Murayama K, et al. (2006) Effects of arginine treatment on nutrition, growth and urea cycle function in seven Japanese boys with late-onset ornithine transcarbamylase deficiency. Eur J Pediatr 165, 618-624.

51. Blachier F, M'Rabet-Touil H, Posho L, et al. (1993) Intestinal arginine metabolism during development. Evidence for de novo synthesis of L-arginine in newborn pig enterocytes. Eur J Biochem 216, 109-117.

52. Crenn P, Messing B \& Cynober L (2008) Citrulline as a biomarker of intestinal failure due to enterocyte mass reduction. Clin Nutr 27, 328-339.

53. Cellini C, Xu J \& Buchmiller TL (2006) Effect of esophageal ligation on small intestinal development in normal and growth-retarded fetal rabbits. $J$ Pediatr Gastroenterol Nutr 43, 291-298.

54. Upperman JS, Potoka D, Grishin A, et al. (2005) Mechanisms of nitric oxide-mediated intestinal barrier failure in necrotizing enterocolitis. Semin Pediatr Surg 14, 159-166.

55. Liu Y, Huang J, Hou Y, et al. (2008) Dietary arginine supplementation alleviates intestinal mucosal disruption induced by Escherichia coli lipopolysaccharide in weaned pigs. Br J Nutr 100, 552-560.

56. Tan B, Yin Y, Kong X, et al. (2010) L-Arginine stimulates proliferation and prevents endotoxin-induced death of intestinal cells. Amino Acids 38, 1227-1235.

57. Hyoh Y, Ishizaka S, Horii T, et al. (2002) Activation of caspases in intestinal villus epithelial cells of normal and nematode infected rats. Gut 50, 71-77.

58. Wu G \& Meininger CJ (2002) Regulation of nitric oxide synthesis by dietary factors. Annu Rev Nutr 22, 61-86.

59. Jacinto E, Facchinetti V, Liu D, et al. (2006) SIN1/MIP1 maintains rictor-mTOR complex integrity and regulates Akt phosphorylation and substrate specificity. Cell 127, 125-137.

60. Cochard A, Guilhermet R \& Bonneau M (1998) Plasma growth hormone $(\mathrm{GH})$, insulin and amino acid responses to arginine with or without aspartic acid in pigs. Effect of the dose. Reprod Nutr Dev 38, 331-343.

61. Park MS, Yang YX, Shinde PL, et al. (2010) Effects of dietary glucose inclusion on reproductive performance, milk compositions and blood profiles in lactating sows. J Anim Physiol Anim Nutr (Berl) 94, 677-684.

62. Bjorkman O, Crump M \& Phillips RW (1984) Intestinal metabolism of orally administered glucose and fructose in Yucatan miniature swine. J Nutr 114, 1413-1420.

63. Drakos E, Rassidakis GZ \& Medeiros LJ (2008) Mammalian target of rapamycin (mTOR) pathway signalling in lymphomas. Expert Rev Mol Med 10, e4.

64. Inoki K, Li Y, Zhu T, et al. (2002) TSC2 is phosphorylated and inhibited by Akt and suppresses mTOR signalling. Nat Cell Biol 4, 648-657.

65. Pullen N \& Thomas G (1997) The modular phosphorylation and activation of p70s6k. FEBS Lett 410, 78-82.

66. O'Connor PM, Bush JA, Suryawan A, et al. (2003) Insulin and amino acids independently stimulate skeletal muscle protein synthesis in neonatal pigs. Am J Physiol Endocrinol Metab 284, E110-E119. 